\title{
Impact of Knowledge Capital on Performance of Firms: A Case of Firms in Finland
}

\author{
Jorma LEHTIMAKI ${ }^{*}$, Jonne LEHTIMAKI ${ }^{* *}$
}

\begin{abstract}
Knowledge capital has become a major factor in a firm's success. Depending on the owner knowledge capital can be divided into individual and organisational capital. The former is an individual's knowledge which is comparable to liabilities in the balance sheet. The latter is connected to a firm's structure and resources, and is comparable to equities in the balance sheet. Measuring knowledge capital is challenging, as it is often necessary to study private information from within a firm. This article approaches knowledge capital from a different perspective by studying public information in order to measure the financial value added by knowledge capital observed from a firm's financial statement. This information was used to explain the financial performance of a firm.

The results of the study indicate a statistically significant effect between the change in individual capital and economic performance as well as between organisational capital and economic performance. The immediate effect of individual capital on economic performance as well as the change in organisational capital was found to be statistically insignificant. The results imply that a firm looking for short-term growth should invest in organisational capital whereas a firm looking for long-term growth should invest in individual capital.
\end{abstract}

Keywords: Knowledge capital; individual capital; organisational capital; measuring knowledge capital, financial statement

JEL Code Classifications: M12, M20, M41, M34

UDC: 005.336 .4

DOI: https://doi.org/10.17015/ejbe.2016.018.03

\footnotetext{
*Adjunct Professor, Department of Economics, University of Turku, Finland. Email: jorleh@utu.fi ** Project Researcher, Research Unit of Sociology of Education, University of Turku, Finland. E-mail: joleht@utu.fi
}

Copyright @ , 2016 International Ataturk Alatoo University. 


\section{Introduction}

As societies have advanced, knowledge in a literal, oral, audio-visual or digital form has become more important for a firm's performance. This is apparent in the countless numbers of product innovations ranging from electric lights to mobile devices as well as in improvements in the manufacturing process such as automatisation and other innovative methods. If a firm can create, learn or adopt and commercially benefit from innovations and new information, it will be successful, especially if it can do this faster than competing firms.

Due to this change, knowledge has become an important factor in the success of a firm. During the last decades, this has meant a shift to an economy, where the relative importance of knowledge to economic success has become higher in comparison to financial or real capital. In economics, growth has been measured with endogenous growth models, where innovation is an important factor.

It has been said that a successful firm has more knowledge capital, often referred to as information capital, intellectual capital or human capital, than their competitors. Depending on the context, knowledge capital can mean anything ranging from immaterial rights to all the knowledge a firm possesses. Knowledge capital sometimes refers to intangible capital, social capital or confidence capital. For example, intangible capital does not only mean the immaterial goods, contracts or immaterial rights listed in balance sheets. The non-structured terminological use of the term "knowledge capital" supports a vague content.

In the so called knowledge-intensive organisations (KIOs), different forms of knowledge are both a raw material of production as well as the final product. In $\mathrm{KIOs}$ the core actions of production processes (production, marketing and distribution) include knowledge processing. For example, in universities, knowledge (material) is processed in research (knowledge as production technology) and the product is knowledge, which is distributed in education or as research reports (for example Lehtimäki, 1993). This means that KIOs need a relatively higher amount of knowledge capital, instead of physical or financial capital, in comparison to other types of organisations. A knowledge-intensive organisation can be, for example, a hospital, a research institution or an education institution, a consulting company or a law firm, and if we consider emotional experiences as knowledge, a theatre group or an orchestra. This article refers to knowledge as a resource and a capital good in any firm, not just in knowledge-intensive organisations.

Knowledge capital is often considered a factor which functions outside balance sheets. This article attempts to study knowledge capital as a component of a firm's assets and debts, in theory and in practice. The study begins by defining knowledge capital and reviewing basic literature about the subject. After which the following steps are taken: 
- constructing a virtual balance sheet where various knowledge capital items are specified

- constructing which items in the income statement can be used to study knowledge capital

- studying whether these items explain the economic performance of a firm.

The empirical data used is information from the 500 largest public and private companies in Finland. The study approaches organisations from a firm-level point of view, but the results and methods can be generalised to study other economic agents.

\section{The Definition of Knowledge Capital: Literature Review}

Sveiby and Lloyd (1987) were the first to define knowledge capital as a micro-level concept by categorising it into human capital (the education and experience of workers), structural capital (ability to organise) and relationship capital (stakeholder relations). This definition of knowledge capital is followed by, for example, Edvinsson and Malone (1997), Nurmi (1998), Black and Lynch (2005), Lönnqvist, Kujansivu and Antola (2005) and Piekkola (2011). Pulic (2000) uses the term intellectual capital, but also divides it into human and structural capital.

Lev (2001) uses the term intangibles dividing it into discovery, organisational practices and human resources. Corrado, Hulten and Sichel (2005) write about knowledge companies, but mostly use the term intangibles dividing it into three categories: computerised information (software and databases), innovative property or discovery (patents, copyrights, designs, trademarks), and economic competencies (brand equity, networks of people and institutions, firm-specific human know-how, etc.).

Kaplan and Norton (2004) divide intangible capital into human capital, knowledge capital and organisational capital. The Meritum-workgroup (2001) recommended using the term intellectual capital, which is divided between human capital and internal and external structural capital. Piekkola (2011) refers to capital created within a firm as the company's own intellectual capital as opposed to intellectual capital purchased from external sources. He divides the intellectual capital of a firm into three fields: knowledge capital and communication technology capital, research capital and development capital, and organisational capital. In the same research report, Piekkola also uses the term human capital when referring to the knowledge of workers.

In the next chapter an explanation is given as to why it is practical to divide knowledge capital between individual capital and organisational capital. Piekkola (2011) notes that services and consumables purchased from outside the firm might involve knowledge capital. In this study organisational capital includes the implicit potential or skill of using external services or equipment, for example, computer programs. 


\subsection{Individual capital}

Some of the information of a firm is in the expertise of workers. Many articles refer to all knowledge capital as human capital, so in order to make the distinction clear, we use the term individual capital to refer to the knowledge capital of workers. Individual capital cannot be used by the firm before a worker is hired and is no longer available if the worker leaves the firm, even if some of his knowledge or experience was gained while working for the firm.

Individual-bound information consists of the talent and the experience of a worker. Experience consists of theoretical education and practical work (Poikela, 1998: 37). Combining these two factors creates experiential knowledge. Experience should be considered as the core of the learning process and it can help in suspending the difference between theory and practice. For example, education should not be considered a process of spreading knowledge (from the point of view of a teacher or an institution), but rather a process of generating experience. This means that there is no clear-cut frontier between theoretical and practical knowledge and learning leads to expertise.

A substantial part of individual capital is created by the firm. McKinsey and Company (2015) have, in their survey, used the following classification of the most important methods of creation of individual capital:

- on-the-job teaching

- one-time internal courses conducted in a classroom setting

- formal or informal coaching

- individual online courses or exercises

- series of internal courses or programmes conducted in a classroom setting

- group-based online courses or exercises

- mobile learning exercises (e.g. podcasts, videos, job aids)

- off-site experiential learning programmes (e.g. in model factories or model offices).

It is interesting to note, that the survey by McKinsey and Company concludes that senior level education is not as important in increasing the efficiency of a firm as the education of frontline employees. Mid-level management and technical specialists are also important, as well as frontline supervisors.

Table 1 presents some measurable individual-bound sets of knowledge capital. They are mostly based on the report of Kujansivu et al. (2007). They list some of the ways knowledge capital can be observed in firms. Many of these variables are interpersonal between an employee and his/her superior. For example, good management may mean an employee's willingness to trust in his/her peers or in senior management and it having an impact on commitment or job satisfaction, as Bakay (2015) has empirically tested. 


\section{Table 1. Measures of Individual-bound Knowledge Capital}

\begin{tabular}{|c|c|c|}
\hline $\begin{array}{l}\text { Type of knowledge } \\
\text { capital }\end{array}$ & Form of manifestation & Measurement \\
\hline $\begin{array}{l}\text { Education background } \\
\text { of personnel (learning } \\
\text { ability) }\end{array}$ & $\begin{array}{l}\text { The highly educated } \\
\text { personnel }\end{array}$ & $\begin{array}{l}\% \text {-shares of personnel with degrees of } \\
\text { advanced, middle and primary education }\end{array}$ \\
\hline $\begin{array}{l}\text { Development of } \\
\text { personnel }\end{array}$ & Development activities & $\begin{array}{l}\text { Training costs in total per key employees } \\
\text { Time spent on education per person } \\
\text { The average satisfaction of the personnel } \\
\text { with his/her development }\end{array}$ \\
\hline \multirow[t]{3}{*}{ Practical work } & Job rotation & $\begin{array}{l}\text { Annual share of personnel participating in } \\
\text { job rotation }\end{array}$ \\
\hline & Life experience & $\begin{array}{l}\text { Average age of personnel, proportion of } \\
\text { personnel over } 50 \text { years old }\end{array}$ \\
\hline & Work experience & $\begin{array}{l}\text { Average experience of personnel in the firm } \\
\text { Average experience of personnel in the } \\
\text { industry } \\
\text { Proportion of new personnel in the firm }\end{array}$ \\
\hline $\begin{array}{l}\text { Motivation of } \\
\text { personnel }\end{array}$ & Level of motivation & $\begin{array}{l}\text { Survey of personnel } \\
\text { Evaluation of a manager }\end{array}$ \\
\hline $\begin{array}{l}\text { Personality traits of } \\
\text { personnel }\end{array}$ & $\begin{array}{l}\text { Big five, self-awareness, } \\
\text { sensitivity, risk taking } \\
\text { capacity }\end{array}$ & Tests \\
\hline Managerial quality & Good management & $\begin{array}{l}\text { Survey of personnel } \\
360^{\circ} \text { assessment } \\
\text { Managerial education }\end{array}$ \\
\hline
\end{tabular}

Not all knowledge gained from experience is easy to define. This kind of knowledge is called tacit knowledge ${ }^{1}$ or skill. Nonaka and Takeuchi (1995: 59-70) describe the formation of all information as a dialogue between tacit (hidden) knowledge and observable (exact) knowledge. Both of these are found in every firm. Knowledge is created from combining exact knowledge, learning by doing, and constructing interaction. Tacit knowledge forms in the mind of a worker and it increases with experience and interactions, remains in a person's memory and becomes apparent in values, intuitions, beliefs, skills and knowledge. It is impossible to document and therefore is hard to transfer to others.

Exact knowledge consists of words, signs, gestures or other explicit forms in books, articles, databases, and so on. Exact knowledge is systematic, can be communicated and can be rather easily transferred from one person to another. An individual's personality can also be presumed to affect his or her performance. Talent, motivation and health are personal traits, but a firm can also affect these traits and their growth.

\footnotetext{
${ }^{1}$ Originally the idea of tacit knowledge was introduced by Polanyi (1967), but for a more recent study see, for example, Salmela (2014) or Schoenherr, Griffith and Chandra (2014).
} 


\subsection{Organisational capital}

When a firm consists of more than a small number of people, there is a need for a system which combines all the factors of production, an organisation. Organisational structure defines a system for the division of labour and authority and for a more formal coordination than just mutual agreements.

When the degree of systematicity in the organisation increases, the knowledge capital necessary for communication and coordination can be called organisational capital. It consists of, for example, routines and procedures, models of division of labour and hierarchy, incentive systems for personnel, working culture, research and development and the different forms of functions and information. In addition to the internal properties of a firm, organisational capital can contain information from external stakeholder networks. These can be, for example, customer loyalty, distribution networks, strategic alliances and commercial strengths. Organisational capital can be divided between structural capital and relationship capital (Konrad Arbetsgruppen, 1989, Lehtimäki, 2005, Kujansivu et al., 2007). In this article this division is not used, therefore organisational capital is a general term for both.

Table 2 contains some possible organisation-bound items of knowledge capital which can be measured in practice. Motivational features in the table are based on the variables in the model by Oldham and Kulik (1984). Work (as an organisational feature) can also be used to indicate knowledge capital. For example, Danchev and Sevnic (2012) assume that there are positive relationships between willingness to work, the rise of knowledge and skills and job satisfaction.

It is possible to split the individual capital and organisational capital of a firm between general and firm-specific capital. The former is usable outside the firm and the latter only within a specific firm (Tomer, 1987). They can be anchored to individuals or structures of a firm, or to both. However, this additional division does not change individual or organisational linkages of knowledge capital.

According to the study by McKinsey and Company (2015) customer demand and strategic importance have become the most important factors of development for a firm to remain competitive. Competitiveness/competitors' capabilities used to be the most important factor. In order of priority these factors are followed by:

- primary drivers of value,

- importance of the organisational culture (i.e. it is a "learning organisation"),

- long-term global trends (e.g. global manufacturing footprint),

- results of capability-related diagnostics (e.g. industry benchmarks), and

- short-term external events (e.g. economic volatility).

When a firm invests in machinery, the leaders of a firm consider which sources of capital to use for the investments. Likewise, when improving the knowledge capital of a firm, the leaders must consider whether it is more beneficial to invest in individual capital or organisational capital. 
Impact of Knowledge Capital on Performance of Firms: A Case of Firms in Finland

\section{Table 2. Different variables and measurement methods of organisational capital.}

\begin{tabular}{|c|c|c|}
\hline $\begin{array}{l}\text { Type of knowledge } \\
\text { capital }\end{array}$ & Form of manifestation & Measurement \\
\hline \multirow[t]{6}{*}{ Innovativeness } & Research and development & R \& D of net sales \\
\hline & & Number of brands \\
\hline & & $\begin{array}{l}\text { Share of new products (number, } \\
\text { turnover) }\end{array}$ \\
\hline & Markets & Number of new market areas \\
\hline & & Number of new business areas \\
\hline & & Number of new customers \\
\hline \multirow[t]{2}{*}{ Internal structures } & $\begin{array}{l}\text { Flexibility of internal } \\
\text { structures }\end{array}$ & $\begin{array}{l}\text { Share of projects based on cooperation } \\
\text { between departments, } \%\end{array}$ \\
\hline & & $\begin{array}{l}\text { The average satisfaction of employees } \\
\text { with the organisation of work } \\
\text { Employee turnover }\end{array}$ \\
\hline \multirow[t]{2}{*}{$\begin{array}{l}\text { The functioning of } \\
\text { processes }\end{array}$} & Uniform routines & $\begin{array}{l}\text { Share of documented processes of all } \\
\text { processes }\end{array}$ \\
\hline & & $\begin{array}{l}\text { Proportion of the critical processes } \\
\text { with the procedural document }\end{array}$ \\
\hline \multirow[t]{6}{*}{$\begin{array}{l}\text { Customer } \\
\text { relationships }\end{array}$} & $\begin{array}{l}\text { Effectiveness of customer } \\
\text { relationships }\end{array}$ & $\begin{array}{l}\text { Customer visits to the company } \\
\text { Visit dates at the customers }\end{array}$ \\
\hline & Customer loyalty & $\begin{array}{l}\text { Proportion of long-term }(>5 \mathrm{y}) \\
\text { customers of all customers }\end{array}$ \\
\hline & & $\begin{array}{l}\text { Proportion of sale for long-term } \\
\text { customers, } \%\end{array}$ \\
\hline & & Share of re-buys of sales total \\
\hline & Customer satisfaction & $\begin{array}{l}\text { On time deliveries defined by } \\
\text { customers }\end{array}$ \\
\hline & & The amount of reclamations \\
\hline \multirow[t]{3}{*}{$\begin{array}{l}\text { Motivational features } \\
\text { of jobs }\end{array}$} & $\begin{array}{l}\text { Skill variety, task identity, } \\
\text { task significance }\end{array}$ & Job diagnostic survey \\
\hline & Autonomy & \\
\hline & Feedback & \\
\hline
\end{tabular}

\section{Knowledge Capital in a Firm's Financial Statement}

The annual report is a part of a firm's financial statement. Some of the private information of a firm can be observed from the annual report. However, in this article the annual report only refers to the income statement and the balance sheet of a firm. The assets listed in the balance sheet describe the firm's resources. The liabilities listed in the balance sheet describe the sources of equity or debts and together they are debts which the firm is accountable for. The balance sheet describes the health of the firm and this information can be used to make some conclusions about the firm's future prospects. 


\subsection{The Balance Sheet}

The assets in the balance sheets are generally divided between tangible and intangible goods and money. Another method is to divide the assets between noncurrent and current sets, and then they are often referred to with the terms immaterial property, real property and financial property. They can be observed from the firm's balance sheet. Shareholders' equity can be calculated by deducting liabilities from assets. Assets are expected to generate revenue in the future. The accumulation of property is always preceded by cash flow and investments or storing produced goods.

A firm is required to use its assets in the balance sheet efficiently in order to succeed in the market. If knowledge could be valued, it would be listed as current and non-current property.

When studying knowledge capital, the main focus should be on the part of a firm's value which exceeds the value of the real capital, financial capital and immaterial goods in its possession. Accounting standards require a firm to report its financial status, profit and cash-flow and they can be studied to estimate the difference, the exceeding value. This value can be called the value of knowledge. The organisationspecific part can be considered to be non-current and the individual-specific part a current reserve of knowledge. Here knowledge, or information, is considered a general term and is not restricted to definable immaterial rights like patents or copyrights.

A firm's liabilities are divided between equities, debts and their intervals. Intervals can be, for example, provision reserves. The division is based on who owns the capital and whether the firm owes the capital to someone or not. When knowledge in its different forms is considered a financial asset, it can be defined as capital based on who owns it. Knowledge in a firm can be in databases, structures, routines, culture or in the workers.

Individual capital can be related to the liabilities in a balance sheet as it cannot be used by the firm before a worker is hired or after the worker leaves the firm. In this sense the firm loans individual capital for a set amount of time and pays for it with wages and other personnel costs. Wages can be considered as interest paid for debts. Interest rates, like wages, can only be observed from the income statement, but the remaining debts are liabilities.

Organisational capital forms a reserve of knowledge which remains in the firm independent of individuals. If organisational capital could be valued in the assets of a firm, it would be closely related to equities. In the theoretical balance sheet, organisational capital represents the value of the firm which exceeds the bookkeeping value. This is comparable to the part of revenue that is not distributed as dividends, and remains in equities to ensure finances and increases the firm's value. 
The theoretical balance sheet including knowledge capital both in assets and liabilities is presented in Table 3. Some of the individual-bound information can also be firm-bound. This means individual knowledge which is not usable in other organisations. This is lost when the worker leaves the organisation and may incur some additional costs for the firm, as it has to train a new worker to perform the same task. This kind of knowledge capital, which is both individual- and organisation-bound, could be considered similar to provisions, a set between equities and liabilities.

\section{Table 3. Theoretical balance sheet}

\begin{tabular}{lc}
\hline Capabilities \& knowledge capital in balance sheet \\
\hline Assets & Owners' equity and liabilities \\
Fixed assets & Owners' equity \\
Tangible assets & Paid-in capital \\
Intangible assets & Retained earnings \\
Organisational capabilities & Organisational capital \\
Current assets & Net profit for the year \\
Individual capabilities & Liabilities \\
Inventories & Long-term liabilities \\
Receivables & Individual capital \\
Bank and cash & Long-term finance liabilities \\
& Short-term liabilities \\
& Individual capital \\
& Current finance liabilities \\
\hline
\end{tabular}

\subsection{Income statement}

One method of measuring intellectual capital is the Value Added Intellectual Coefficient (VAIC ${ }^{\mathrm{TM}}$ ) formulated by Pulic (2000). This has been used with varying results by, amongst others, Appuhami (2007), in order to study Thailand's banking sector, Tan, Plowman and Hancock (2007) the stock exchange of Singapore, Laing, Dunn and Hughes-Lucas (2010) the Australian hotel sector, Molodchik and Bykova (2011) Russian industrial enterprises, Dimitropoulos and Koumanakos (2015) European football clubs and Parham and Heling (2015) to study Dutch production companies. It has also been applied to the banking sector for Poland by Śledzik (2013), in India by Narwal and Sushila (2015), for Islamic banks by Ousama and Fatima (2015) and for the Egyptian insurance market by Sherif and Elsayed (2016). Pulic (2004) himself as well as Nazari and Herremans (2007) have extended the model, Volkov (2012) has written a literary review on the model and its use and Young et al. (2009) argue that the method can be used to describe the market value of a business much better than traditional financial indicators. Pulic (2008) also further examined the concept of intellectual capital efficiency and how VAIC ${ }^{\text {TM }}$ can be used to study it.

$\mathrm{VAIC}^{\mathrm{TM}}$ is based on calculating different aspects of a firm's performance and adding them together to produce a measurement of intellectual capital. Pulic (2000) 
calculates value-added (= output, i.e. revenues, total sales - a sum of all the bought expenses for the generation of the output), and the value of three types of intellectual capital: human capital (=labour costs), structural capital (= value added - labour costs), and capital employed (=real and financial capital).

Pulic (2000) then calculated the ratio between each of the three forms of capital and value-added, resulting in capital employed efficiency (VA/CA), human capital efficiency (VA/HU), and structural capital efficiency (ST/VA, calculated differently due to the fact that human capital and structural capital are in reverse proportions). To calculate an overall measure of efficiency, Pulic adds together the three efficiency measures: VAIC=VACA+VAHU+STVA. This Value Added Intellectual Coefficient, $V A I C^{T M}$ indicates the firm's value creation efficiency. The higher the VAIC $^{T M}$ coefficient, the better the management has utilised the company's potential.

Ståhle, Ståhle and Aho (2011) have conducted an extensive study on the measurement method and show that the summed total results are not relevant, even though the individual parts of the model have a rational foundation. Even if the sum structure of VAIC is questionable, it is justified to presume that the amount of knowledge capital in a firm has a direct effect on its economic performance ${ }^{2}$.

A firm's business result can be observed in the income statement and its financial status in the balance sheet. The values in the financial statement have also been used to study the ratio of knowledge capital to other forms of capital. Sveiby (2010) has defined three different methods for using this kind of data for measuring knowledge capital:

- the difference of market value and financial statement value,

- economic value added (EVA ${ }^{\mathrm{TM}}$ ), and

- measuring knowledge capital directly from financial statements.

The first approach is to study a firm's bookkeeping value, which can be observed from the adjusted balance sheet. The difference between a firm's market value and book value can be interpreted as the market's financial valuation of a firm's knowledge capital. This valuation is similar to the balance sheet in Table 3, but the value of a firm's properties is defined by the market rather than the firm's leaders. In this approach, a firm's value has to be defined by the market; therefore it can only be used for publicly traded firms. Firms, which have not been listed on a stock exchange, do not have a strictly defined market value.

The second approach is to study the Economic Value Added. Economic Value Added (EVA) is an estimate of a firm's economic profit or the value created in

\footnotetext{
${ }^{2}$ See, for example, Blundell, Dearden, Meghir and Sianesi (1999) for a review on the economic effect of human capital.
} 
excess of the required return of the firm's shareholders. Quite simply, EVA is the net profit less the opportunity cost of the firm's capital. The idea is that value is created when the return on the firm's economic capital exceeds the cost of said capital. This method is advantageous for comparing firms, but requires some knowledge about the owners' demands for the rate of return.

Sveiby's third approach is to measure knowledge capital directly from financial statements, in this case from income statements, without using the coefficients of VAIC. The personnel costs listed in the income statement is the compensation paid to workers for allowing their individual capital (knowledge, creativity and motivation) to be used by a firm. For this to hold true we have to assume that the collective labour agreements or contracts of employment have succeeded reasonably well in pricing the value of an employee. Wage levels, in general, are determined by the competence of an employee and the demands of her/his job.

By subtracting the wages from the total value added by a firm, the remaining value can be interpreted as the organisational capital, which the firm has included in the price of its products. In practice, the division of added value between individual capital and other forms of knowledge capital cannot be measured with definite accuracy and some generalisations are necessary.

Increase in value can be calculated as:

increase in value $=$ revenue + other proceeds $-($ materials + services +

other expenses + depreciation)

or

increase in value $=$ business result + personnel costs

Compensations for equities and liabilities are paid from this measure of value added. In the model a full compensation for organisational knowledge and market knowledge are presumed to be included in prices. Knowledge used for acquisition and utilisation of machines and services is a part of a firm's knowledge capital as well as a part of individual capital and organisational capital.

Chapter 4 considers whether the sets of knowledge capital measured from the income statement have an effect on the economic performance of a firm.

\section{The Connection between Economic Performance and Knowledge Capital in the Income Statement of A Firm}

\subsection{Data and methodology}

The economic performance of a firm can be measured with several different methods. Productivity is often used and is defined as:

productivity $=\frac{\text { value added }}{\text { personnel costs }}$

where:

value added $=$ business result + depreciation + personnel costs 
The measure in equation (3) for productivity describes the portion of value added paid to the personnel. If the measure receives the value 1 , the firm has used its whole value added on personnel costs. The higher is the value of the measure, the higher is the productivity of labour.

Productivity is just one method of measuring economic success. A firm can perform poorly in the market and still be very productive. Some other measures of a firm's performance can be observed from income statements and financial statements. For example:

- the annual change in turnover and profit

- earnings before interests and taxes (EBIT, \%)

- return on equity (ROE, \%)

- return on investment (ROI, \%)

- earnings per share (EPS)

- $\mathrm{P} / \mathrm{E}-, \mathrm{P} / \mathrm{BV}$ - or P/S-ratio

- dividend payout ratio (\%)

- total shareholder return (\%).

From these possible measures, return on investment is quite independent from the size of the firm or the market, the number of owners, or industry. The effects of knowledge capital can be presumed to be independent of the source of funding and therefore using return on investment as the measure of economic success seems reasonable.

Invested capital consists of equities (tied-up capital and any capital that has not been distributed to owners) and interest-bearing liabilities. The study tests the following hypotheses:

- there is an immediate positive effect between knowledge capital and the economic performance of a firm.

- there is a positive effect between knowledge capital and the future economic performance of a firm.

- there is a positive effect between increasing knowledge capital and the economic performance of a firm.

The data was collected from the 500 largest firms in Finland in the years 2005-2008 as listed in the Talouselämä 500 -database (2010). From these 500, sufficient adjusted financial statement data (revenue, personnel costs, earnings before interests and taxes, invested capital and its return margin) was available for 376 firms. In the results, growth refers to relative growth in the studied time series. There is sufficient variation and observations in this adjusted sample to study whether investments to individual or organisational capital have had an effect on financial performance. The approach of this study is similar to Chen, Cheng and Hwang (2005) who use partial least squares, a form of the structural equation modelling method, to study the efficiency of Taiwanese listed companies. They 
study the relationship between corporate value creation efficiency and market-tobook value ratios as well as the relationship between intellectual capital and the current and future financial performance of firms ${ }^{3}$.

The study is done with Ordinary Least Squares regressions with the financial performance and the growth of a firm as the dependent variable. The significance of the proxy variables for individual capital and organisational capital as well as their change during the studied time series are studied for individual years as well as the whole sample. Individual capital is measured by the wages paid by a firm. The data consist of several different kinds of firms and an attempt was made to eliminate the distorting effect of firm size on individual capital by also studying the relation of total wages to revenue. This did not seem to eliminate the effect of differences between industries.

The following model was used to test the hypothesis:

$\Delta r o i=\alpha+\beta_{1} I N D C A P_{i t}+\beta_{2} O R G C A P_{i t}+\varepsilon_{i t}$

where roi is the change in return on investment, INDCAP is the variable for individual capital and the change in individual capital when so listed and ORGCAP is the variable for organisational capital and the change in organisational capital when so listed.

Figure 1 describes the studied relationships. The proxy variables for firm-level individual capital, organisational capital and economic performance were calculated from data available in financial statement statistics. The study is done on the immediate effect of investment in different forms of capital as well as the effect of the change in investment of different forms of capital.

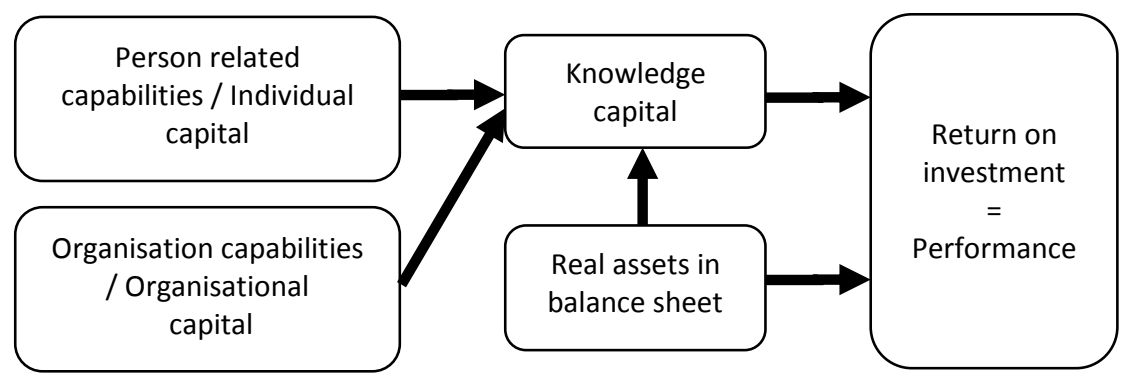

Figure 1. The effects described in the three hypotheses

\subsection{Results}

Organisational capital was measured by deducting wages (=individual capital) from the value added by the firm. Dividing this measure by revenue was done in order to

\footnotetext{
${ }^{3}$ As an interesting side note, Chen, Cheng and Hwang (2005) also study how investors value a firm and find that they may place different value on the three components of value creation (physical capital, human capital and structural capital).
} 
diminish the effect of firm size. However, the division does not eliminate the disparity in firm size. In the results TO refers to turnover.

Table 4 lists the results for return on investments for the year 2008. The effect of the relation between individual capital and revenue on economic performance, and the return on investment, was statistically insignificant for every year in the data. The same holds true for the relation between individual capital and revenue in 2005 on the return on investment in 2008. Organisational capital had a statistically significant effect on the return on investment in the years 2005, 2006 and 2007, but not in 2008. This might be caused by the sudden change in the business cycle in 2008. When the data was restricted to firms with positive return on investment, a similar statistical significance was observed.

Table 4. ROI -\% as dependent variable in 2005-2007

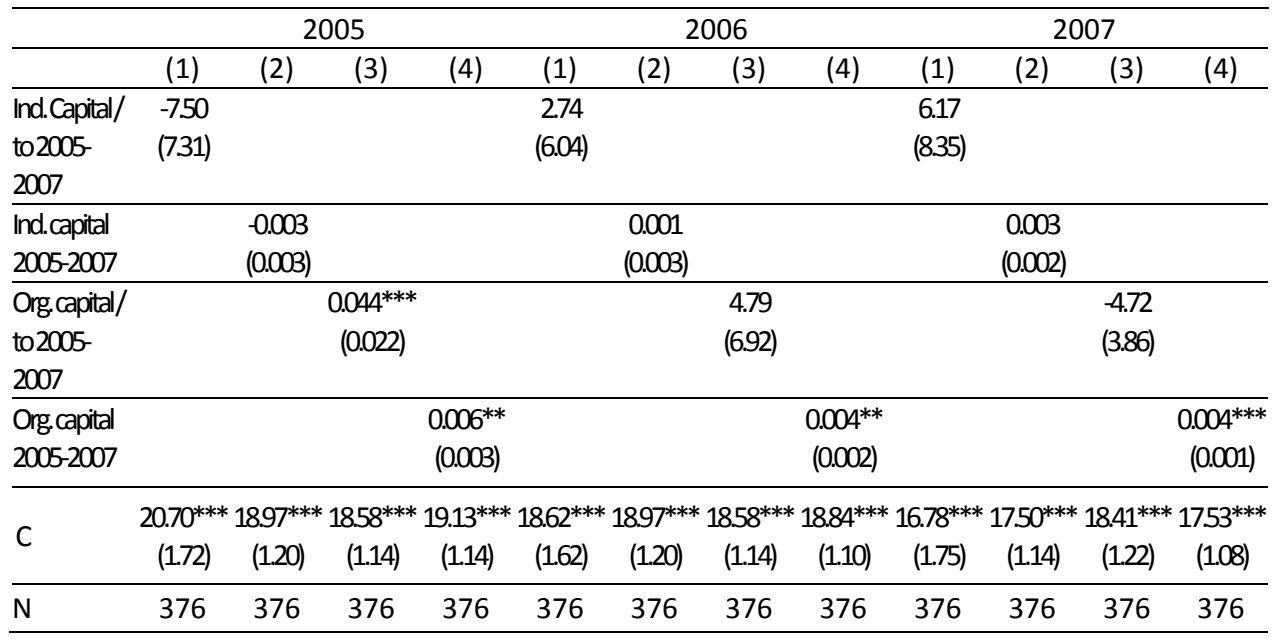

Table 5 lists the results of the change in return on investment during the sample. The change in the relation between individual capital and revenue and the change in individual capital on economic performance were statistically significant as well as the effect on the changes in individual capital. It can be concluded that the increase in personnel improves the company's economic performance, at least in the short run.

Table 6 lists the effects of different variables on the return on investment for the final year of the sample. The relation between organisational capital and revenue in 2005 had a statistically significant effect on the return on investment in years 2005 and 2008. The relation between organisation capital and revenue in 2008 had a statistically significant effect on the return on investment in 2008 , but there was no effect in years 2006 and 2007. The changes in organisational capital had no statistically significant effect in any of the studied cases. 
Impact of Knowledge Capital on Performance of Firms: A Case of Firms in Finland

Table 5. Change in ROI-\% in 2005-2008 as dependent variable

\begin{tabular}{lcccc}
\hline & $(1)$ & $(2)$ & $(3)$ & $(4)$ \\
\hline Ind. capital/Change in To 05-08 & $0.29^{*}$ & & & \\
Change in ind. capital 05-08 & $(0.16)$ & & & \\
& & $0.39^{* * *}$ & & \\
Org. capital/Change in To 05-08 & & $(0.09)$ & & \\
& & & -0.0007 & \\
Change in org. capital 05-08 & & & & \\
& & & & $-0.0001)$ \\
C & -16.33 & $-27.77^{* *}$ & $-20.49^{*}$ & $(0.001)$ \\
& $(12.41)$ & $(12.41)$ & $(12.06)$ & $(12.06)$ \\
\hline $\mathrm{N}$ & 376 & 376 & 376 & 376 \\
\hline
\end{tabular}

Table 6. ROI-\% as dependent variable in $\mathbf{2 0 0 8}$

\begin{tabular}{|c|c|c|c|c|c|c|c|c|c|c|c|c|}
\hline & (1) & (2) & (3) & (4) & (5) & (6) & (7) & (8) & (9) & (10) & (11) & (12) \\
\hline \multirow{2}{*}{\multicolumn{13}{|c|}{$\begin{array}{lc}\text { Ind.Capital/ } & 2.82 \\
\text { Tumover05 } & (10.13)\end{array}$}} \\
\hline & & & & & & & & & & & & \\
\hline \multicolumn{13}{|l|}{ Ind.capital } \\
\hline \multicolumn{13}{|l|}{05} \\
\hline \multicolumn{13}{|l|}{ Ind.Capital/ } \\
\hline to 08 & & & (10.91) & & & & & & & & & \\
\hline \multicolumn{13}{|l|}{ Ind.capital } \\
\hline 08 & & & & $(0.001)$ & & & & & & & & \\
\hline \multicolumn{13}{|l|}{ Ind.capital/ } \\
\hline Changeinto & & & & & $0.04^{* *}$ & & & & & & & \\
\hline $05-08$ & & & & & $(0.02)$ & & & & & & & \\
\hline \multicolumn{13}{|l|}{ Changein } \\
\hline ind.capital & & & & & & $0.07^{* * *}$ & & & & & & \\
\hline $05-08$ & & & & & & $(0.02)$ & & & & & & \\
\hline \multicolumn{13}{|l|}{ Org.capital/ } \\
\hline \multicolumn{13}{|l|}{ to 05} \\
\hline \multicolumn{13}{|l|}{ Org.capital } \\
\hline \multicolumn{13}{|c|}{$(0.002)$} \\
\hline \multicolumn{13}{|l|}{ Org.capital/ } \\
\hline \multicolumn{13}{|l|}{ to 08} \\
\hline \multicolumn{13}{|l|}{ Org.capital } \\
\hline \multicolumn{13}{|l|}{08} \\
\hline \multicolumn{13}{|l|}{ Org.Capital } \\
\hline /Changein & & & & & & & & & & \multirow{2}{*}{\multicolumn{3}{|c|}{$\begin{array}{l}-0.0002 \\
(0.0002)\end{array}$}} \\
\hline to $05-08$ & & & & & & & & & & & & \\
\hline \multicolumn{13}{|l|}{ Changein } \\
\hline org.capital & & & & & & & & & & & & 0.0001 \\
\hline $05-08$ & & & & & & & & & & & & $(0.0002)$ \\
\hline \multirow[t]{2}{*}{$\mathrm{C}$} & $14.44^{* * *}$ & $15.04 * * *$ & $1293^{* * *}$ & $14.79 * * *$ & $1558^{* * *}$ & $13.64^{* * *}$ & $13.06^{* * *}$ & $14.81^{* * *}$ & $16.68 * * *$ & $15.08^{* * *}$ & $14.98^{* * *}$ & $14.63^{* * *}$ \\
\hline & (255) & $(147)$ & (232) & (142) & $(147)$ & (114) & (1.16) & $(137)$ & $(147)$ & (142) & (136) & (135) \\
\hline $\mathrm{N}$ & 376 & 376 & 376 & 376 & 376 & 376 & 376 & 376 & 376 & 376 & 376 & 376 \\
\hline
\end{tabular}




\section{Conclusion and Discussion}

A firm's knowledge capital consists of organisational capital and individual capital. The former consists of the structures and processes of the organisation and relations to other firms and the latter of the theoretical and practical experience of workers. Individual capital is comparable to debt in the balance sheet and it is lost if the worker leaves the firm. In the assets of a firm, it is comparable to short-term assets. Organisational capital can be compared to equities and it is the knowledge fixed to a firm's structures and processes and is not dependent on individual workers. It is comparable to permanent assets.

It is difficult to measure the amount of knowledge capital in a firm. Most of the measurements require private internal knowledge about a firm. These are, for example, the theoretical (education) and practical experience of workers, motivations, quality of leadership, internal structures, processes and customer relations.

In this article, the value added by a firm in the income statement was used as a proxy to measure the financial value of knowledge capital. The value added was divided between the value of individual capital and organisational capital. These variables and their changes were used to study knowledge capital's effect on the economic performance of a firm, which was measured by the annual return on investment. The data used was compiled from the financial statements of Talouselämä-magazine's database as regards the 500 largest firms in Finland.

The results were mixed. Some of the studied cases showed a statistically significant effect on the economic performance of a firm and some did not. The results might be affected by the sudden economic downturn in the final year of the sample, but in principle the change in the business cycle should not have an effect on the relative changes of the variables.

The effect of the relative amount of organisational capital, as it was defined in this article, on return on investment is self-evident despite the sample consisting of firms of different sizes and years with varying economical atmospheres. The growth of the proxy for individual capital, total wages, had a positive effect on the return on investment. This means that firms were able to hire workers who increased the value added by the firm more than their wages.

These results imply that investing in organisational capital has an immediate effect on the economic performance of a firm whereas investing in individual capital has a lagged effect. A firm looking for immediate economic growth should invest in organisational capital whereas a firm looking for longer-term growth should invest in individual capital. A possible direction for future research would be to divide the 
Impact of Knowledge Capital on Performance of Firms: A Case of Firms in Finland

data by industries. Another possible direction would be to extend the methods used in this article to study the effect of intellectual capital in the public sector ${ }^{4}$.

\section{References}

Appuhami, R. (2007). The impact of intellectual capital on investors' capital gains on shares: an empirical investigation of Thai banking, finance and insurance sector. International Management Review, 3 (2), 14-25.

Bakay, A. (2015). Does Interpersonal Trust Influence Organizational Behavior? Eurasian $\begin{array}{lllll}\text { Journal of Business and Economics, } 8 \text { (15), 219-238. } & \text {. }\end{array}$ https://doi.org/10.17015/ejbe.2015.015.11

Black, S.E. \& Lynch, L.M. (2005). Measuring Organizational Capital in the New Economy. In Corrado, C., Haltiwanger, J., \& Sichel, D. (Eds.) Measuring Capital in the New Economy (pp. 205-236). Chicago: The University of Chicago Press. https://doi.org/10.7208/chicago/9780226116174.003.0007

Blundell, R., Dearden, L., Meghir, C. \& Sianesi, B. (1999). Human Capital Investment: The Returns from Education and Training to the Individual, the Firm and the Economy. Fiscal Studies, 20 (1), 1-23. https://doi.org/10.1111/j.1475-5890.1999.tb00001.x

Chen, M.C., Cheng, S.J. \& Hwang, Y. (2005). An empirical investigation of the relationship between intellectual capital and firms' market value and financial performance. Journal of Intellectual Capital, 6 (2), 159-176. https://doi.org/10.1108/14691930510592771

Corrado, C., Hulten, C. \& Sichel, D. (2005). Measuring Capital and Technology: An Expanded Framework. In Corrado, C., Haltiwanger, J., \& Sichel, D. (Eds.) Measuring Capital in the New Economy (pp. 11-46). Chicago: The University of Chicago Press. https://doi.org/10.7208/chicago/9780226116174.001.0001

Danchev, A. \& Sevnic, E. (2012). Willingness to Work, Human Capital and Job Satisfaction: A Case Study for Turkey. Eurasian Journal of Business and Economics, 5 (10), 71-90.

Dimitropoulos, P.E. \& Koumanakos, E. (2015). Intellectual capital and profitability in European football clubs. International Journal of Accounting, Auditing and Performance Evaluation, 11 (2), 202-220. https://doi.org/10.1504/IJAAPE.2015.068862

Dumay, J., Guthrie, J. \& Puntillo, P. (2015). IC and the public sector: a structured literature review. Journal of Intellectual Capital, 16 (2), 267-284. https://doi.org/10.1108/JIC-02-20150014

Edvinsson, L. \& Malone, M.S. (1997). Intellectual capital: Realizing Your Company's Real Value by Finding Its Hidden Brainpower. New York: HarperBusiness.

Kaplan, R.S. \& Norton, D.P. (2004). Strategy Maps: Converting Intangible Assets into Tangible Outcomes. Massachusetts: Harvard Business Review Press.

Konrad Arbetsgruppen (1989). Den osynliga balansräkningen. Affärsvärdens Förlag: Visby.

Kujansivu, P., Lönnqvist, A., Jääskeläinen, A. \& Sillanpää, V. (2007). Liiketoiminnan aineettomat menestystekijät: mittaa, kehitä ja johda. Helsinki: Talentum Media Oy.

Laing, G., Dunn, J. \& Hughes-Lucas, S. (2010). Applying the VAIC ${ }^{\mathrm{TM}}$ model to Australian hotels. Journal of Intellectual Capital, 11 (3), 269-283. https://doi.org/10.1108/14691931011064545

\footnotetext{
${ }^{4}$ For example Dumay, Guthrie and Puntillo (2015) suggest how intellectual capital works in the public sector.
} 
Lehtimäki, J. (1993). Towards a theory of the university as a knowledge-intensive organisation. Publications of Turku School of Economics, Series A.

Lehtimäki, J. (2005). Tieto yrityksen pääomana ja tiedon hankkimisen taloustieteelliset piirteet. In Vihanto, M. (Ed.) Instituutiotaloustieteen nykyisiä suuntia. Tampere: Research on Finnish Society.

Lev, B. (2001). Intangibles. Management, Measurement, and Reporting. Washington, D.C.: Brookings Institution Press.

Lönnqvist, A., Kujansivu, P. \& Antola, J. (2005). Aineettoman pääoman johtaminen. Tampere: Aavaranta-sarja. JTO-Palvelut Oy.

McKinsey \& Company (2015). Building capabilities for performance. McKinsey \& Company: Insights and Publications.

Meritum-Workgroup (2001). Aineettoman varallisuuden johtamisen ja raportoinnin periaatteet. Elinkeinoelämän tutkimuslaitoksen julkaisuja. Sarja B186. Helsinki: Taloustieto Oy.

Molodchik, M. \& Bykova, A. (2011). Applying the VAIC'M Model to Russian Industrial Enterprises. In Proceedings of the $3^{\text {rd }}$ European Conference on Intellectual Capital, 3, 268277. Academic Conferences Limited

Narwal, K.P. \& Sushila, S. (2015). Intellectual capital performance in Indians banks: a panel data analysis. International Journal of Learning and Intellectual Capital, 12 (2), 103-121. https://doi.org/10.1504/IJLIC.2015.068983

Nazari, J.A. \& Herremans, I.M. (2007). Extended VAIC model: measuring intellectual capital components. Journal of Intellectual Capital, 8 (4), 595-609. https://doi.org/10.1108/14691930710830774

Nonaka, I. \& Takeuchi, H. (1995). The Knowledge Creating Company. How Japanese Create the Dynamics of Innovation. Oxford: Oxford University Press.

Nurmi, R. (1998). Knowledge-intensive firms. Business Horizons, 41 (3), 20-32.

Oldham, G.R. \& Kulik, C.T. (1984). Motivation Enhancement Through Work Redesign. In Bess, J.L. (Ed.) College and University organization, (pp. 85-104). New York: New York University Press. https://doi.org/10.1016/s0007-6813(98)90005-2

Ousama, A.A. \& Fatima, A.H. (2015). Intellectual capital and financial performance of Islamic banks. International Journal of Learning and Intellectual Capital, 12 (1), 1-15. https://doi.org/10.1504/IJLIC.2015.067822

Parham, S. \& Heling, G. W. (2015). The relationship between human capital efficiency and financial performance of Dutch production companies. Research Journal of Finance and Accounting, 6 (8), 188-201.

Piekkola, H. (2011). Aineeton pääoma - avain menestykseen. Vaasan yliopiston julkaisuja. Selvityksiä ja raportteja 169.

Poikela, E. (1998). Oppiminen, arviointi ja osaaminen. In Räisänen, A. (Ed.) Hallitaanko ammatti? Pätevyyden määrittelyä arvioinnin perustaksi. Opetushallitus: arviointi 2.

Polanyi, M. (1967). The Tacit Dimension. New York: Anchor Books.

Pulic, A. (2000). VAIC ${ }^{\mathrm{TM}}$ - an accounting tool for IC management. International Journal of Technology Management, 20 (5-8), 702-714. https://doi.org/10.1504/IJTM.2000.002891 
Pulic, A. (2004). Intellectual capital - does it create or destroy value? Measuring Business Excellence, 8 (1), 62-68. https://doi.org/10.1108/13683040410524757

Pulic, A. (2008). The principles of intellectual capital efficiency: a brief description. Retrieved October 1, 2016 from http://www.cik-hr.com/data/principles_2008.pdf

Salmela, P. (2014). Hiljainen tieto, innovaatio ja IT. Helsinki: Ketterä Kirjat Oy.

Schoenherr, T., Griffith, D.A. \& Chandra, A. (2014). Knowledge Management in Supply Chains: The Role of Explicit and Tacit Knowledge. Journal of Business Logistics, 35 (2), 121135. https://doi.org/10.1111/jbl.12042

Sherif, M. \& Elsayed, M. (2016). The impact of intellectual capital on corporate performance: Evidence from the Egyptian insurance market. International Journal of Innovation Management, 20 (3), 1-47. https://doi.org/10.1142/s1363919616500341

Śledzik, K. (2013). The Intellectual Capital Performance of Polish Banks: An application of

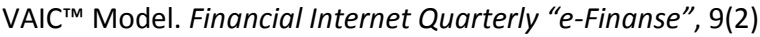

Ståhle, P., Ståhle, S. \& Aho, S. (2011). Value added intellectual coefficient (VAIC): a critical analysis, Journal of Intellectual Capital, 12 (4), 531-551. https://doi.org/10.1108/14691931111181715

Sveiby, P.-E. (2010). Methods for measuring Intangible Assets. Retrieved August 8, 2015 from http://www.sveiby.com/articles/IntangibleMethods.htm

Sveiby, P.-E. \& Lloyd, T. (1987). Managing knowhow. London: Bloomsbury.

Talouselämä-Magazine (2010). Suomen suurimmat yritykset. Retrieved August 1, 2010 from http://www.talouselama.fi/te500/

Tan, H.P., Plowman, D. \& Hancock, P. (2007). Intellectual capital and financial returns of $\begin{array}{llllll}\text { companies. Journal of Intellectual Capital, } 8 & \text { (1), }\end{array}$ https://doi.org/10.1108/14691930710715079

Tomer, J.F. (1987). Organizational capital. New York: Praeger Publishers.

Volkov, A. (2012). Value Added Intellectual Co-efficient (VAIC $\left.{ }^{T M}\right)$ : A Selective ThematicBibliography. Journal of New Business Ideas \& Trends, 10 (1), 12-24.

Young, C.S., Su, H.Y., Fang, S.C. \& Fang, S.R. (2009). Cross-country comparison of intellectual capital performance of commercial banks in Asian economies. The Service Industries Journal, 29 (11), 1565-1579. https://doi.org/10.1080/02642060902793284 